\title{
E-Government Interoperability: Architecture Model for Public Information Services of Sub- District Governments
}

\author{
Djalal Er Riyanto ${ }^{1,}$, Panji Wisnu Wirawan ${ }^{1}$, and Kabul Kurniawan ${ }^{1}$ \\ ${ }^{1}$ Departemen of Computer Science, FSM, Diponegoro University, Semarang, Indonesia
}

\begin{abstract}
Sub-District Government as a Public Bodies is such a state administrator in accordance to the law required to apply disclosure, either by publishing information proactively, and or providing information application services. Implementation of e-Government is one solution that can be used to improve performance in running the mandate of the law. EGovernment requires collaboration from various Public Bodies, especially in data exchange, information sharing, and processes. E-Government Interoperability is the development of inter e-Government systems for sharing and integrating information using shared standards. The success of e-Government Interoperability is determined by strategies, policies, and architectures that enable data, information technology systems, business processes, and service lines to integrate precisely and efficiently. The architectural model generated from this study illustrates the structure of eGovernment Interoperability, the basic organization of system components, the relationship of one component with other components and the environment. Model validation uses result approach/theory analysis for data standardization, solid platforms, easier access to information, and efficient administration and services. The architectural model can serve as a guide for design and evolution, in an effort to create a system for public information services, especially at the sub-district level. It was concluded that the model was able to realize the development of sub-district vertical database integration and single-sign-on.
\end{abstract}

\section{Introduction}

The Public Information Disclosure Act gives individuals the right to access information controlled or administered by the Public Agency [1]. It is obliged to apply disclosure, either proactively publishing information, and/or by providing a request for information services. E-Government is broadly defined as the use of information and communication technologies to support government tasks, such as providing or improving public services or managing internal government operations [2].

Benefits of e-Government can be expanded and enhanced with interoperability applied, which is system information technology and communication also business process supported, to be able to exchange data and able to share information and knowledge by

* Corresponding author: erriyanto@undip.ac.id 
using common standard [3]. Interoperability involves various parties, inter-agency, crosssector so that need willingness and mutual understanding to make it happen.

The architectural model called Kenyan e-Government Architecture [4] consists of five layers, ranging from the technology layer to the presentation layer. Another model is a model with four layers, with two layers between them the same as the previous model [5].

In this research, we will examine the non-technical and technical problems to facilitate e-Government Interoperability. Non-technical issues relate to laws and regulations used in order to realize public information services by the government, and from a technical point of view the environment and model of sub-district level information service architecture.

\section{Methodology}

The three main questions that will be answered in this research are: a) the main information needed to realize public information disclosure in accordance with the law, b) technical and non-technical factors that support the realization of interoperability, and c) architectural model for e-Government Interoperability of public information services the sub-district governments to be used as the basis for implementing the e-Government.

Exploration and study is a preliminary study to obtain materials from literature and observation, related to public agencies, as well as applicants and public information users. As a result, the data and formulation, as well as infra-structure of information and communication technology for public information services of local government (subdistricts) are gathered. The analysis stages produce an environmental analysis covering the technical and non-technical environments of e-Government Interoperability, as well as the factors needed to support the success of e-Government Interoperability. Architectural modelling begins with initial modelling, then validation to ensure that the resulting model meets the model objectives/outputs.

\section{Result and Discussion}

\subsection{Reviews of laws and regulations}

Broadly, there are three norms related to public information disclosure, namely: basic norms, general norms, and technical norms [6]. The basic norm contains articles derived from the 1945 Constitution of the Republic of Indonesia [7]. General norms of laws and regulations related to information disclosure [1][8][9][10]. Technical norms contains a provision which provides guidance and information disclosure mechanism to realize public information disclosure [11][12][13]. Everyone has the right to communicate and obtain information to develop his or her personal and social environment; as well as the right to seek, obtain, possess, store, process and convey information by using all kinds of available channels [7].

Rural community has the right to gain access information through village information systems managed by the rural government. Rural Development Information Systems and Rural Area Development shall be developed by the regency/city government, and are designed to ensure the right of information access to the village [10]. Public information services are provided through the Information and Documentation Service Room [10], or the Information Desk [11]. Public Information and Documentation System is provision information system and documentation service, that it is quickly, easily and fairly in accordance with the law on freedom of information [13].

Information Management and Documentation Officer (IMDO) is the official responsible in the field of storage, documentation, provision, and/or information service in the Public 
Agency and directly responsible to the supervisor of IMDO [11]. The Information and Documentation Service Manager is the organizer of information and document management services within the Ministry of Home Affairs and Local Government [10]. Rural Information System includes rural data, rural development data, rural area, as well as other information relating to rural development and rural area development.

Rural information through government organizations and departments web sites consist of: a) Potential Rural from The Central Bureau of Statistic, b) Rural and Village Profiles from the Ministry of Home Affairs, c) Rural Community Online from The Ministry of Village, and d) Rural Broadband from the Ministry of Communication and Information.

\subsection{Interoperability Environment}

Interoperability involves various components, namely: a) data sources and service providers for public, b) applicant user Information, c) supporters, d) laws/regulations, and e) ministry web / government agencies.

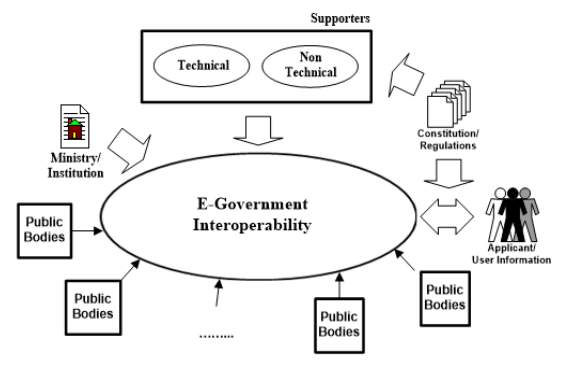

Fig 1. Environmental e-Government Interoperability

Data sources and public service providers come from various public organizations, especially those located within the districts and also stakeholders. Applicant/User Information is those who need data/information or services from E-Government, or those who are targeted to obtain information in relation to government programs. Supporters consist of technical and non-technical components. Technical component consists of information technology and communication infrastructures at each Public Agency. Nontechnical supporters include policy and political will as the key success of interoperability. Laws and regulations provide guidance for the development of interoperability, among others, in determining the types of data and information that must be provided and accessible to the public, relations between public agencies, and public service mechanisms. Web Ministries/Agencies are a web related to the management of rural and data village developed, among others by the Ministry of Internal Affairs, Central Bureau of Statistics, and Ministry of Village. The Web is a study material to get the benchmark data of rural and districts in national level.

\subsection{Model Architecture for e-Government Interoperability}

Architecture is a picture of the structure of a system that describes the basic organization of components, linked to one another with their environment, with principles guide the design and evolution [15]. The architecture is addressed to three things: a) the design is adapted to what is required, not limited to the available technology, b) the effective architecture will accelerate service delivery for the market and lead to cost savings, and c) the architecture should support the overall flexible public services [16].

Architecture development principles of e-Government Interoperability are: a) to use of basic needs in regulations and legislation provided, b) the architectural design has 
the scalability, thus the implementation and development must be able to adapt to development needs and technological readiness also human resources, and c) to focus on efforts to improve the quality of public services gradually and sustainably.

The e-Government Interoperability architecture is designed to have a number of interconnected components, and the environment of e-Government Interoperability. By adopting the given architecture [4][5], the architectural model for e-Government Interoperability has four layers as a component (see Figure 2 ).

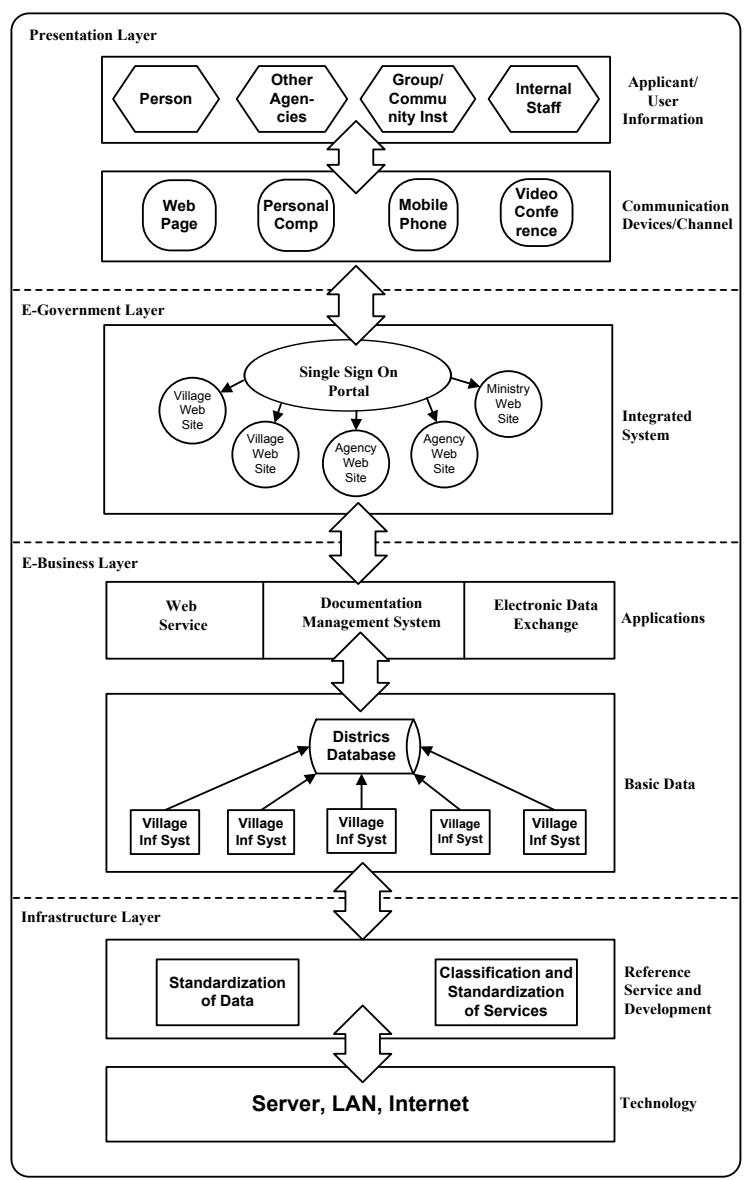

Fig 2. Architecture of e-Government Interoperability

Infrastructure Layer:

Infrastructure Layer consists of two main parts, namely: technology, as well as reference services and development. Technology consists of information and communications technology hardware needed to data capture, perform processing, storage of results, and devices for the distribution of data and information. The Service and Development Reference consist of two sub-sections, namely: a) data standardization, used to eliminate problems caused by multiple independent data processors, and b) Qualification and standardization of services, used to build systems with services integrated and standardized. Both sections are indispensable for interoperability, and subsequent developments.

E-Business Layer 
E-Business Layer consists of two parts, namely: basic data, and applications. Basic data is data and processing results that can be accessed through e-Government Interoperability. The data is managed in the sub-district database, and for the long-term period it will form a sub-district data warehouse in the form of historical data obtained from system or operational applications. From various rural information systems an access mechanism will be built to realize "one-door management in obtaining information and analyzing it for decision making"

\section{E-Government Layer}

This layer integrates digital data from various organizations into a web portal of government services, in the form of one-stop e-Government portals or single sign on portals, which systems inside different computer networks to provide easy and secure access to multi sub-systems once authenticated, including mandatory and user access permissions. This has resulted in increased access, reduced process service costs, and enabled the availability of services that are easy and fast. To realize e-Government Layer required political policy and the willingness of all stakeholders.

\section{Presentation Layer}

The top layer contains facilities for presenting result to applicants and or users of information, whose nature of services are official or non-official. For such service, it needs communication device or channel required, which can be webpage, personal computer, mobile equipment or video conference. By those devices, applicant/user Information can access various information and services of public organization.

\section{Model Validation}

The model validation for this research uses the results/theoretical approach to four results/outputs, namely: data standardization, solid platform, easier information access, and efficient administration and services. Data standardization can be realized through the integration of data from various rural information systems into sub-district databases, as well as the adoption of data structures of various information systems developed by various local and central ministries/agencies. A solid platform for realizing inter-system interoperability, document flow efficiency, and inter-company transactions is available through the use of web service applications, document management systems, and electronic data exchange. Easier and cheaper access to public information is available through an open interface with communication or channel equipment that is widely known, owned and operated by the public. Public administration and services are more efficient through "vertical integration", and also by developing Single-Sign-On.

\section{Conclusion}

Regulations and legislation mandate the need for a broader and more accessible public information service system. The model of the District-level e-Government Interoperability Architecture can be used as a guide in the effort to realize the mandate, through the use and development of an integrated and sustainable information system. Using model validation with the results / theory analysis approach, it was concluded that the model was able to realize the development of sub-district vertical database integration and single-sign-on portal. The implementation of the architectural model of e-Government Interoperability is carried out by optimally utilizing the existing information systems, as well as supporting the willingness of all relevant parties based on the spirit to implement the laws and regulations. 


\section{References}

1. __ Law of The Republic of Indonesia Number 14 Year 2008 concerning Public Information Openness.

2. Novakouski, Marc, and Grace A. Lewis, Interoperability in the e-Government Context, Carnegie Mellon University, 2012.

3. Gottschalk, Petter, and Hans Solli-Saether, e-Government Interoperability and Information Resource Integration: Framework for Aligned Development, IGI Global, 2009.

4. Mose, S.M., Wafula J.M., Kimani S., e-Government Architecture Model for Government-to-Government Deployment of Interoperable Systems (A Case Study of County National Government In Kenya), International Journal of Innovative Research in Technology and Science (IJIRTS), Volume 3, Number 3, ISSN: 2321-1156.

5. Ebrahim, Zakareya, and Zahir Irani: e-Government adoption: architecture and barriers, Business Process Management Journal, Vol. II No. 5, 2005.

6. Prayitno, Dessy Eko, et. al., Module for Public Bodies, Implement The Law Number 14 of 2018 concerning Public Information Openness, Indonesian Center for Enviromental Law, 2013.

7. __ The 1945 Constitution of the Republic of Indonesia.

8. _ _ Law of the Republic of Indonesia Number 25 of 2009 concerning Public Service.

9. ___ Law of The Republic of Indonesia Number 43 of 2009 concerning Archieves.

10. ___ Law of The Republic of Indonesia Number 6 of 2014 concerning Village.

11. __ Information Commission Regulations Number 1 of 2010 concerning Public Information Service Standards.

12. ___ Information Commission Regulations Number 2 of 2010 concerning Procedures for Resolving Public Information Disputes.

13. __ Indonesians Republic's Home Affairs Minister Regulation Number 3 of 2017 concerning Guidelines for Management of Information and Documentation Services of The Ministry Home Affairs and Regional Government.

14. __ Ministry of Home Affairs Regulation Number 12 of 2007 concerning Guidelines for the Preparation and Utilization of Village and Village Profile Data.

15. Stevanus van Staden, e-Government Interoperability: A Cooperative Architecture Model to Facilitate Information Sharing in Namibia, A Thesis Submitted in Partial Fulfilment of The Requirements of Master of Science in Information Technology of The University of Namibia, 2011.

16. Lallana, Emmanuel C., e-Government Interoperability, United Nation Development Programme, 2008. 